\title{
冬季夜温の違いがスプレーカーネーションの開花，収量，切り花品質に及ぼす影響
}

\author{
馬場富二夫 * ・石井ちか子・石井香奈子・武藤浩志・稲葉善太郎 \\ 静岡県農林技術研究所伊豆農業研究センター 413-0411＼cjkstart賀茂郡東伊豆町稲取
}

\section{Effects of Winter Night Temperature on the Flowering, Yield and Quality of Cut Flowers in Spray-type Carnation (Dianthus caryophyllus L.) Cultivars}

\author{
Fujio Baba*, Chikako Ishii, Kanako Ishii, Hiroshi Muto and Zentaro Inaba \\ Izu Agricultural Research Center, Shizuoka Prefectural Research Institute of Agriculture and Forestry, 3012 Inatori, Higashiizu-cho, Kamo, Shizuoka \\ 413-0411
}

\begin{abstract}
Effects of winter night temperature $\left(5,10,15\right.$ or $\left.20^{\circ} \mathrm{C}\right)$ on the flowering, yield and quality of spray-type carnation (Dianthus caryophyllus L.) 'Light Pink Barbara' and 'Cherry Tessino' were investigated. In both cultivars, secondary lateral shoots sprouted after the second decapitation (second pinch lateral shoots) grew more rapidly at higher night temperature, whereas the length of second pinch lateral shoots at anthesis was the longest at the lowest night temperature $\left(5^{\circ} \mathrm{C}\right)$. In both cultivars, the number of days from pinching to flowering decreased, and the yield of cut flowers increased with increasing night temperature. The lowest $\left(5^{\circ} \mathrm{C}\right)$ night temperature adversely affected flower quality, resulting in increased second florets. In 'Cherry Tessino', the red color pigmentation of white marginal variegation of flowers increased up to completely red petals with increasing night temperature. The chromatic component $\mathrm{L}^{*}$ value showed a tendency to decrease with increasing night temperature, and $\mathrm{a}^{*}$ value showed a tendency to decrease at $5^{\circ} \mathrm{C}$. In conclusion, from the perspective of achieving a good balance between productivity and the quality of cut flowers, suitable night temperatures in winter for cut flower production of spray-type carnation 'Light Pink Barbara' and 'Cherry Tessino' are suggested to be 10 to $15^{\circ} \mathrm{C}$.
\end{abstract}

Key Words : days to flowering, flower color, lateral shoot

キーワード : 花色, 側枝, 到花日数

\section{緒言}

静岡県など日本の暖地におけるカーネーション栽培で は，挿し芽発根苗を $6 \sim 7$ 月に定植後摘心， 1 番花を年内 に収穫し, その後に伸長する 2 番花を母の日頃まで収穫す る摘心栽培が一般的に行われ, 冬季には施設内を加温して 生育を維持している(臼井, 1999). 生産地では $10 \sim 13^{\circ} \mathrm{C}$ で冬季の夜温管理を行っているが（鍵野，2009），近年暖房 コストの増加により暖房温度を低く設定する傾向があると いわれ，生育の遅れや切り花品質に及ぼす悪影響が懸念さ れている.

カーネーションの生育や切り花品質は温度の影響を受け ることが知られて扣り（藤野ら，1977b; Holley・Baker, 1963; 小西, 1980; 國本ら，1989), 生育適温は $15 \sim 20^{\circ} \mathrm{C}$ で, 10 $\sim 25^{\circ} \mathrm{C}$ の範囲で生育もよく良質な切り花を生産でき（肥 田，1973），昼温よりも夜温が生育に大きな影響を与える

2009 年 5 月 28 日 受付. 2009 年 11 月 20 日 受理. 本報告の一部は園芸学会平成 21 年度春季大会で発表した。

* Corresponding author. E-mail: fujio1_baba@pref.shizuoka.lg.jp
（Abou Dahab, 1967）。冬季の最低夜温が無加温，5 括よび $10^{\circ} \mathrm{C}$ の処理区では夜温が高いほど採花本数が増加すると されている（藤野ら，1982）が, これらの研究は‘ウィリ アム・シム’, ‘スケニア’, ‘ューラル’, ‘ピーター・フィッ シャ一’など 1 茎 1 花のスタンダードタイプ（以下スタン ダードカーネーション）について行わ机でり，いずれの 品種も現在では汪とんど栽培されていない. 現在栽培され ている切り花用カーネーションには，1 茥に $5 \sim 7$ 輪の側 花を着生するスプレータイプ（以下スプレーカーネーショ ン）も多く（宇田, 2009), 草姿や花色, 花形の多様さから 広く栽培され，普及している．藤野ら（1982）は11月に定 植したスプレーカーネーション“レッド・アイベッテ’ で, 12 月 1 日〜 3 月 1 日まで無加温, 10 打よび $15^{\circ} \mathrm{C}$ の夜温条 件下で切り花品質への影響を検討し，高夜温ほど到花日数 が短く, 低夜温䚾ど茎長, 茥重が大きく, 蕾数が多くなっ たと報告している。しかし，これ以外の生育に及ぼす冬季 夜温の影響についての報告は少ない（米村, 1990a）.

財団法人日本花普及センターの集計によると，スプレー カーネーションの取扱量は, 2006 年の国内 10 市場の集計 で，スタンダードカーネーション，ハイブリッドカーネー 
ション, その他のカーネーションを含む切り花カーネー ション全体の約 48.6\%，2007 年の国内 13 市場の集計で切 り花カーネーション全体の約 $36.8 \%$ となっている（(財) 花 普及センター，2008）。

一般に, スタンダードカーネーションに比ベスプレー カーネーションでは，ガク割れ防止や摘芽などの作業が大 幅に軽減される，この一方で，頂花を摘除して各側花の開 花を揃え, 側花の開花を待って収穫されるため（吉田, 1984), スタンダードカーネーションより到花日数が長くな る。また，スプレーカーネーションは側枝に複数の側花が あるため，施設内の気温に対する開花反応がスタンダード カーネーションとは異なることが考光られる.

さらにスプレーカーネーションでは, 低温条件下で発生 する「孫芽」と呼ばれる 2 次花らいが切り花品質に大きく 影響し，2 次花らいが伸長すると商品価值が低下寸るため, スタンダードカーネーションより高めの温度で管理するこ とが好ましいとされている(細谷, 1999). しかし, 静岡県 内の生産現場では, スタンダードカーネーションとスプ レーカーネーションを含む複数の品種を同一の温度管理で 栽培する施設や, 冬季の夜温を $8^{\circ} \mathrm{C}$ 程度で管理する施設も みられる.

そこで本試験では，暖地の $6 \sim 7$ 月定植のスプレーカー ネーション栽培における好適な冬季夜温管理について検討 するため, 静岡県に拈ける主力品種の ‘ライトピンクバー バラ’と‘チェリーテッシノ’を供試して, これまでの報 告より大きい温度幅での冬季夜温の違いが，スプレーカー ネーションの生育, 収量, 切り花品質に及ぼす影響を検討 したので報告する.

\section{材料および方法}

スプレーカーネーションで早晚性が共に中生（宇田, 2004）の ‘ライトピンクバーバラ (LPB)' と‘チェリー テッシノ $(\mathrm{CT})^{\prime}$ の 2 品種の挿し芽発根苗を種苗会社（フ ジ・プランッ）から購入し，供試材料とした。定植時の苗 は 10 株の平均值で ‘LPB' では葉長 $8 \mathrm{~cm}$ 以上の展開葉数 9.8 枚, 葉の先端までの地上部長 $16.2 \mathrm{~cm}$ で, ‘CT’ では展 開葉数 12.0 枚, 地上部長 $15.4 \mathrm{~cm}$ であった.

静岡農林研伊豆農業研究センタ一南伊豆圃場（静岡県南 伊豆町上賀茂) 内の環境制御温室に抒いて栽培を行い, 冬 季の最低夜温として $5,10,15$ および $20^{\circ} \mathrm{C}$ の 4 処理区を 設定した. 暖房機による加温は, $20^{\circ} \mathrm{C}$ 区も含め, 試験圃場 で最低夜温が $15^{\circ} \mathrm{C}$ を下回る 2007 年 11 月 6 日〜 2008 年 5 月 6 日までの期間に行った. 暖房機が実際に稼働したのは, $5^{\circ} \mathrm{C}$ 区では 2007 年 11 月 19 日〜 2008 年 4 月 7 日, $10^{\circ} \mathrm{C}$ 区 では 2007 年 11 月 12 日〜 2008 年 4 月 22 日で, $15^{\circ} \mathrm{C}$ 区と $20^{\circ} \mathrm{C}$ 区では期間中稼働を続けた. 加温期間中は日中も暖房 機の稼働を続け， 5,10 および $15^{\circ} \mathrm{C}$ の処理区では温室内の 気温が $20^{\circ} \mathrm{C}$ 以上で, $20^{\circ} \mathrm{C}$ 区では $25^{\circ} \mathrm{C}$ 以上で自動的に側空 を開放した。
施設内に自記温度記録計（サーモレコーダーミニ RT-30S およびサーモレコーダーRT-12，エスペックミック）を設 置し, 栽培開始から終了まで, 定植地表面から $1 \mathrm{~m}$ の高さの 気温を RT-30S で，ベッド中央部の深さ $15 \mathrm{~cm}$ の地温を RT12 で 1 時間ごとに測定した.

2007 年 6 月 27 日に定植し， 7 月 19 日に地上部の 6 節を 残して摘心した. 摘心後に発生した 1 次側枝を 4 本に整理 し，最も伸長の早い 1 本を 9 月 7 日に分枝位置から 8 節で 2 次摘心した，側枝の仕立て抢よび採花方法は第 1 図のと おりである (米村, 1990b). すなわち，(1)～(3)は 1 次側枝, (4)および(5) 2 次摘心後に伸長した 2 次摘心側枝, (6) 8 は 1 次側枝(1)〜 (3)を採花後に伸長した 2 次側枝, 数值は採 花順序を示している.

定植床にはポリプロピレン製隔離床（幅 $85 \mathrm{~cm} \times$ 長さ $320 \mathrm{~cm} \times$ 深さ $17 \mathrm{~cm}$ ，スーパードレンベッド 85 , 全農) を 用い，山土（淡色黒ボク土）とバーク堆肥を $2: 1$ に混合した 土壤消毒済久の用土を充填した。栽植密度は株間 $20 \mathrm{~cm} \times$ 条間 $20 \mathrm{~cm}$ の 4 株植えとした.

施肥は基肥を施用せず，エミッターピッチ $20 \mathrm{~cm}$ の点滴 チューブを 2 本設置して行った. 液肥は園試処方（加藤, 1997） $1 / 2$ 単位 ( $\mathrm{N}: \mathrm{P}: \mathrm{K}=121.3 \mathrm{ppm}: 20.6 \mathrm{ppm}: 156.4 \mathrm{ppm}$ ) を基本とし, 著者らのこれまでの試験成績を基に施用した. 施用は 7 月 1 日から開始し， 7〜8月は 1 日扣きに窒素濃 度 $60.7 \mathrm{ppm}$ の液肥を株当たり $50 \mathrm{~mL}, 9 \sim 11$ 月は窒素濃度 $121.3 \mathrm{ppm}$ を株当たり 1 日 $100 \mathrm{~mL} ， 12 \sim 2$ 月は窒素濃度 $121.3 \mathrm{ppm}$ を株当たり 1 日 $50 \mathrm{~mL}, 3$ 月は窒素濃度 $121.3 \mathrm{ppm}$ を株当たり 1 日 $100 \mathrm{~mL}, 4$ 月〜 2 月 5 日まで窒素濃度 $60.7 \mathrm{ppm}$ を株当たり 1 日 $150 \mathrm{~mL}$ 施用した. 5 月 6 日から栽培終了ま では水のみを給液し，栽培期間中の株当たり総窒素施用量 は $2.4 \mathrm{~g}$ とした.

試験規模は 1 区 8 株 3 反復とした。側枝発生位置から先 端までを側枝長とし, 1 次側枝では摘心した側枝以外で最も 伸長の早い側枝について, 2 次摘心側枝では伸長の早い側枝 について，摘心後から採花まで月に 2 回，約 15 日ごとに調 査した．頂花は開花前の花弁が十文字状にみえた状態で摘 除し（堀川，1979; 國本，1993），側花 2 輪が開花した時点 を開花日として採花した. 採花位置は，1 次側枝では頂花か ら第 $7 \sim 9$ 節， 2 次摘心側枝以降では分枝位置からとし, 2008 年 5 月 30 日までの採花本数を調査した。採花した 1 次側枝，2次摘心側枝および最も早い 2 次側枝について，到 花日数（1 次摘心から開花までの日数）, 切り花節数, 切り 花長，切り花重，頂花から第 $4 \sim 5$ 節目の節間長および花 らい数を調査した. 切り花の先端から $45 \mathrm{~cm}$ の位置を水平 に保持した状態の下垂度を調査し，軟弱花を判定した。

2007 年 11 月 29 日， 2008 年 3 月 3 日扎よび 5 月 8 日に, 側枝の上位 2 節目で開花した側花の最外縁部花弁について, 中央部および外縁部の色差を色彩色差計（MINOLTA, CR200）で各 10 花計測した. 


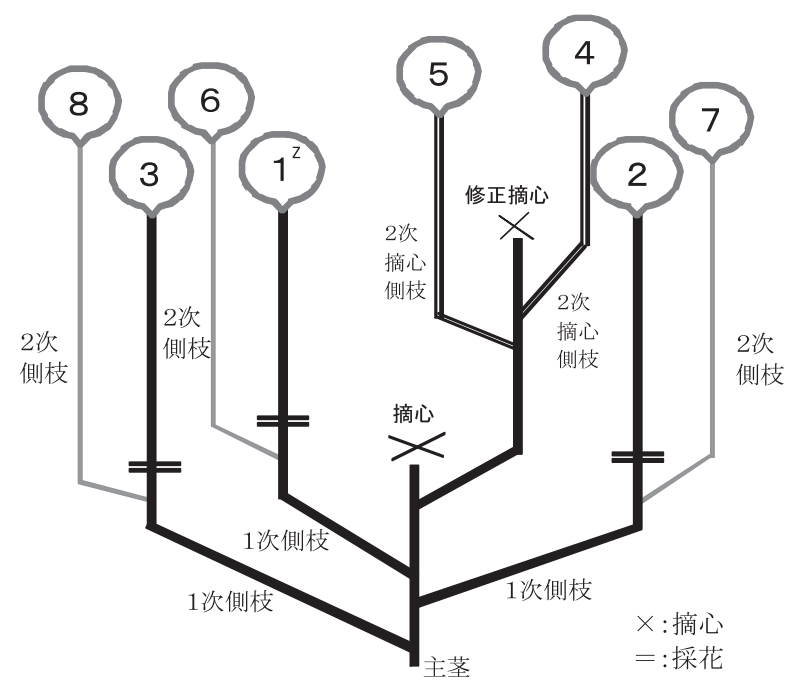

第 1 図 カーネーションの摘心と側枝の模式図 z(1)〜8は收穫した切り花の順序

\section{結果}

2008 年 1 月 19 日における気温, 地温の 1 時間ごとの推 移を第 2 図に示した。夜間の気温は打抢む和設定温度に維

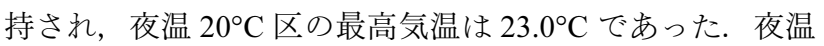
が高い区ほに゙地温も高く推移した.

1 次側枝と 2 次摘心側枝の最も伸長の早い側枝について, 開花時点までの伸長程度を第 3 図に示した. 1 次側枝につ いては 2 品種の側枝の伸長に処理による差はみられなかっ た. 2 次摘心側枝は 'LPB’ で 1 月上旬以降, ‘CT’ では 12 月上旬以降処理による差が認められた. いずれの品種も夜 温が高くなるほど側枝長が長く推移するが，開花時点では 夜温 $5^{\circ} \mathrm{C}$ の側枝長が長くなった。 その後に伸長する 2 次摘 心側枝の側枝長も，同様の傾向を示した（データ略）.

到花日数の調査結果を第 1 表に示した. いずれの品種で も, 夜温が高くなる汪ど 1 次側枝, 2 次摘心側枝, 2 次側枝 の到花日数が短縮した. 夜温による到花日数の違いは 2 次 摘心側枝に打いて最も顕著に現れ, 夜温 $5^{\circ} \mathrm{C}$ と $20^{\circ} \mathrm{C}$ の差 は ‘LPB’ で 64 日， ‘CT’ で54日と最も長くなった。品 種の違いによる側枝別到花日数の差は, 1 次側枝と 2 次側 枝で認められた。なお，同一処理区内に拈いては反復間で 同様の傾向を示した.

採花本数についても，夜温が高い注ど直線的に増加する が，いずれの品種も 3 月末までの低温期に打ける採花本数 の違いによるものであり, 気温の上昇する 4 ～5 月の採花 本数には処理による有意な差は認められなかった(第2表). 時期別採花本数の品種による差は採花開始〜 12月の期間で のみ認められた。

夜温の違いが切り花長，切り花重，節数，節間長，花ら い数に及ぼす影響には品種間差がみられた（第 3 表）。1 次 側枝ではいずれの品種も切り花重のみで差が認められ， 2 次摘心側枝ではすべての調査項目で差が認められた． 2 次

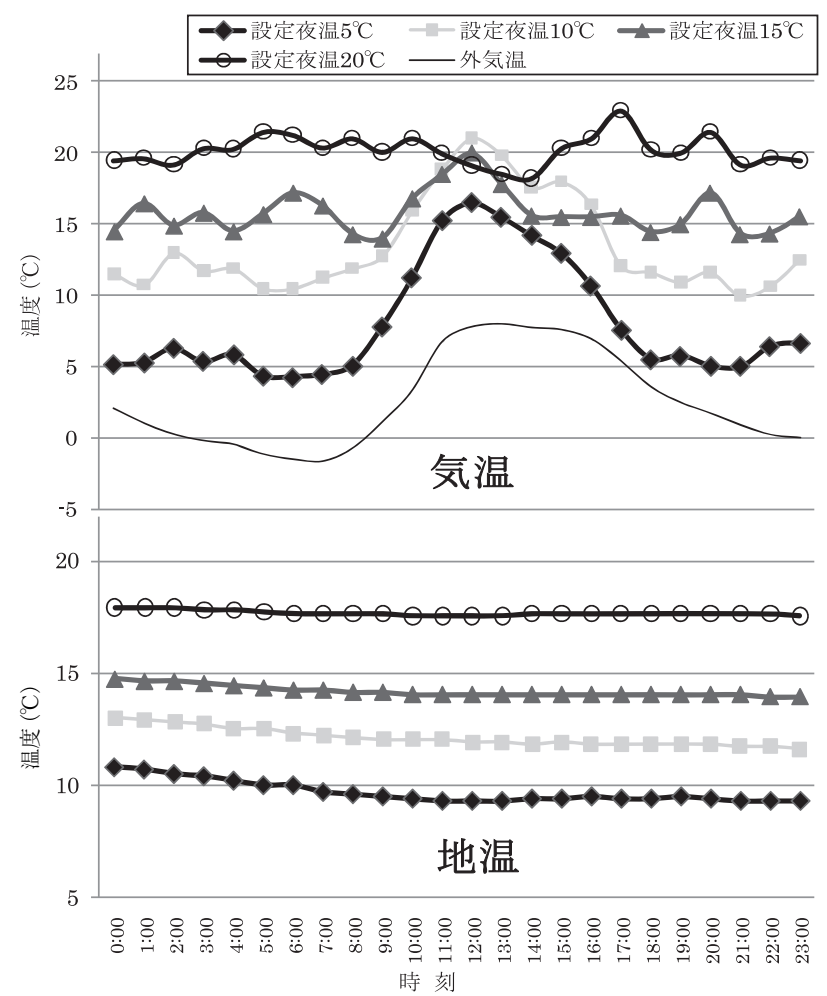

第 2 図 冬季夜温が厳寒期 ${ }^{\mathrm{z}}$ の施設内気温, 地温 ${ }^{\mathrm{y}}$ 推移に及ぼ す影響

${ }^{\mathrm{z}} 2008$ 年 1 月 19 日調査

y ポリプロピレン製隔離床に扔いてベッド中央部深さ $15 \mathrm{~cm}$ を測定

側枝では ‘LPB’ では切り花長，節数，節間長で差が認め られ，“CT’ではすべての調査項目で差が認められた。 た 10 度以上下垂し, 軟弱花と判断される切り花が, 'LPB' の夜温 $20^{\circ} \mathrm{C}$ で年内に多く発生し，“CT’ の夜温 $20^{\circ} \mathrm{C}$ では 収穫期間を通じて発生した（データ略）。

花色の発現に対する影響は品種間で異なり，単色で薄い 桃花の 'LPB’ では調査時期が遅くなるほど明度 L*が高く なり，a*が低くなる傾向がみられたが，いずれの調査時期 に扣いても $a^{*}$ の夜温処理の違いによる影響は認められな かった（第 4 表）。明度 L*，b*についても処理夜温との間 に一定の傾向は認められなかった。 これに対し，桃色に白 の覆輪が入る ‘CT' では, 11 月の調査から, 夜温 $15^{\circ} \mathrm{C}$ と $20^{\circ} \mathrm{C}$ で明度 $\mathrm{L}^{*}$ が低く, a*が高くなり，視覚的にも花色が 濃くなる傾向を示すとともに（第 4 図），夜温 $20^{\circ} \mathrm{C}$ に打い ては外縁部の覆輪が鮮明でなくなるものがあった.

\section{考察}

夜温が側枝の伸長に及ぼす影響は 1 次側枝では認められ ず，2次摘心側枝に打いて認められた． 2 次摘心側枝は ‘LPB'，‘CT’ ともに加温開始から一定期間を経て開花し ていることから，夜温が生育に及ぼす影響は，厳寒期ほど 強く現れると考えられた. これまで夜温とカーネーション の生育との関係を経時的に追跡した報告はみられないが, 

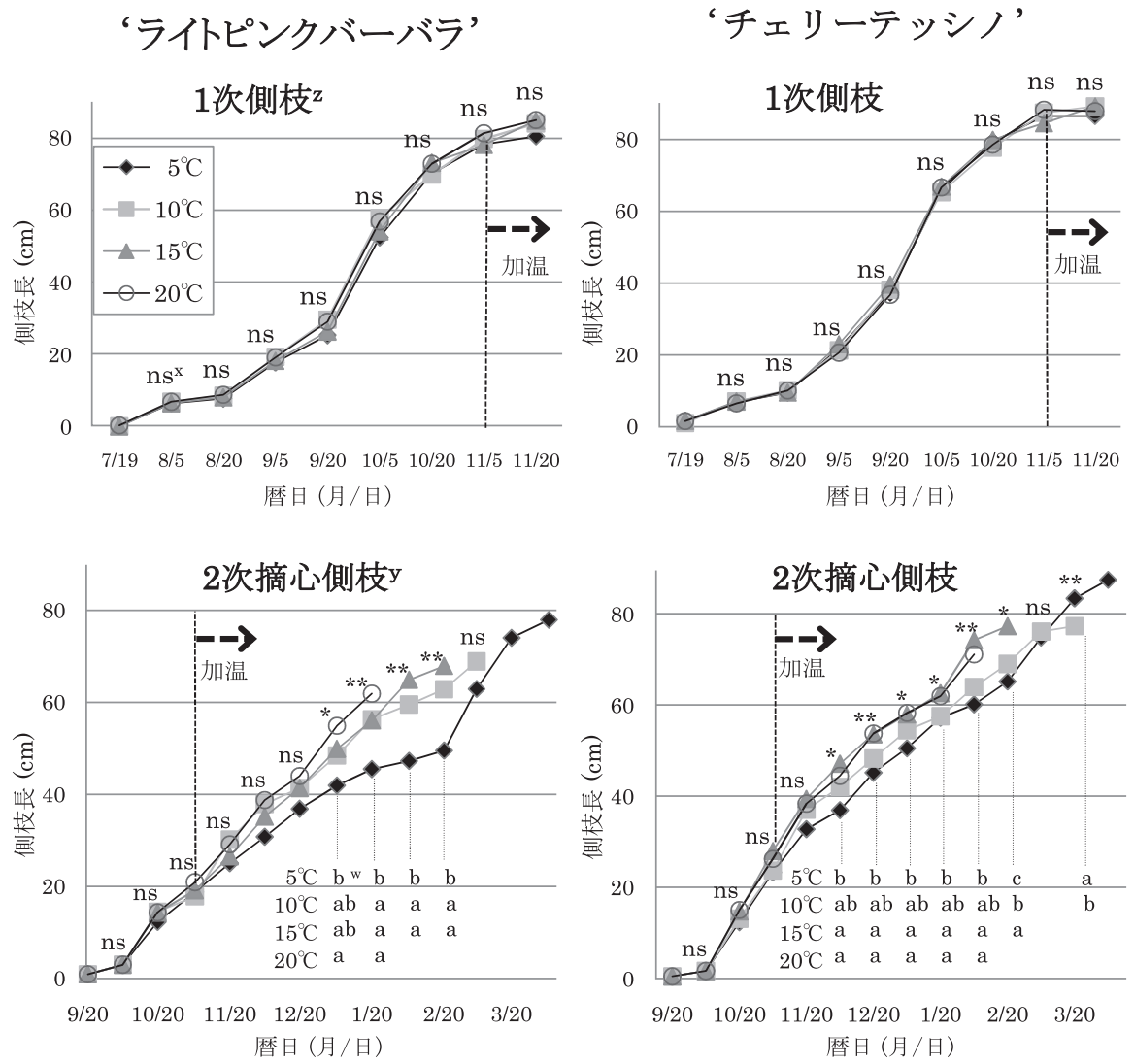

第 3 図冬季夜温が側枝の伸長に及ぼす影響

$\mathrm{z}$ 最も伸長の早い 1 次側枝の側枝長

$\mathrm{y}$ 最も伸長の早い 2 次摘心側枝の側枝長

$\mathrm{x}$ 分散分析により**は1\%，*は5\%水準で有意差あり，ns は有意差なし

w 同符号間は Tukey の多重検定により 5\%で有意差のないことを示す

第 1 表 冬季夜温がスプレーカーネーションの側枝別到花日数に及ぼす影響

\begin{tabular}{|c|c|c|c|c|c|c|c|c|c|c|}
\hline \multirow{3}{*}{ 供試品種 } & \multirow{3}{*}{$\begin{array}{l}\text { 夜温 } \\
\left({ }^{\circ} \mathrm{C}\right)\end{array}$} & \multicolumn{9}{|c|}{ 到花日数 ${ }^{\mathrm{z}}$ （収穫日） } \\
\hline & & \multicolumn{3}{|c|}{1 次側枝 ${ }^{y}$} & \multicolumn{3}{|c|}{2 次摘心側枝 ${ }^{x}$} & \multicolumn{3}{|c|}{2 次側枝 ${ }^{w}$} \\
\hline & & （日） & (月／日） & & （日） & (月 $/$ 日) & & （日） & (月／日） & \\
\hline \multirow{4}{*}{$\begin{array}{c}\text { ライトピンク } \\
\text { バーバラ }\end{array}$} & 5 & 165 & $(12 / 31)$ & $a^{v}$ & 284 & $(4 / 27)$ & $\mathrm{a}$ & 307 & $(5 / 21)$ & $\mathrm{a}$ \\
\hline & 10 & 144 & $(12 / 10)$ & $\mathrm{b}$ & 254 & $(3 / 29)$ & $\mathrm{b}$ & 292 & $(5 / 6)$ & $\mathrm{b}$ \\
\hline & 15 & 145 & $(12 / 11)$ & $\mathrm{b}$ & 247 & $(3 / 22)$ & $\mathrm{b}$ & 287 & $(5 / 1)$ & $\mathrm{bc}$ \\
\hline & 20 & 134 & $(11 / 30)$ & $\mathrm{b}$ & 220 & $(2 / 24)$ & $\mathrm{c}$ & 273 & $(4 / 17)$ & $\mathrm{c}$ \\
\hline \multirow{4}{*}{$\begin{array}{l}\text { チェリー } \\
\text { テッシノ }\end{array}$} & 5 & 140 & $(12 / 6)$ & $\mathrm{a}$ & 277 & $(4 / 20)$ & $\mathrm{a}$ & 298 & $(5 / 12)$ & $\mathrm{a}$ \\
\hline & 10 & 137 & $(12 / 3)$ & $a b$ & 260 & $(4 / 4)$ & $\mathrm{b}$ & 292 & $(5 / 6)$ & $\mathrm{a}$ \\
\hline & 15 & 129 & $(11 / 25)$ & $a b$ & 235 & $(3 / 9)$ & $\mathrm{c}$ & 275 & $(4 / 19)$ & $\mathrm{b}$ \\
\hline & 20 & 125 & $(11 / 21)$ & $\mathrm{b}$ & 223 & $(2 / 26)$ & $\mathrm{d}$ & 267 & $(4 / 11)$ & $\mathrm{b}$ \\
\hline \multirow{3}{*}{ 分散分析 ${ }^{u}$} & 夜温. & $* *$ & & & $* *$ & & & $* *$ & & \\
\hline & 品種 & $* *$ & & & ns & & & $*$ & & \\
\hline & 交互作用 & ns & & & ns & & & ns & & \\
\hline
\end{tabular}

${ }^{\mathrm{z}}$ 摘心（7月19日）から開花までの日数

$\mathrm{y}$ 第 1 図参照, 1 次側枝 3 本の平均

$\mathrm{x}$ 第 1 図参照, 2 次摘心側枝 2 本の平均

w 第 1 図参照, 調査株の最も早い 2 次側枝

v 同一品種間に括いて Tukey の多重検定により同符号間には 5\%水準で有意差のないことを示す

u 分散分析により**は 1\%,*は 5\%水準で有意差あり, ns は有意差なし 
第 2 表 冬季夜温がスプレーカーネーションの株当たり時期 別採花本数に及ぼす影響

\begin{tabular}{|c|c|c|c|c|c|}
\hline \multirow[b]{2}{*}{ 供試品種 } & \multirow{2}{*}{$\begin{array}{l}\text { 夜温 } \\
\left({ }^{\circ} \mathrm{C}\right)\end{array}$} & \multicolumn{4}{|c|}{ 採花本数（本） } \\
\hline & & $\begin{array}{c}\text { 採花開始 } \\
\sim 12 \text { 月 }\end{array}$ & $1 \sim 3$ 月 & $4 \sim 5$ 月 & 合計 \\
\hline \multirow{4}{*}{$\begin{array}{c}\text { ライトピンク } \\
\text { バーバラ }\end{array}$} & 5 & $1.6 \mathrm{~b}^{\mathrm{z}}$ & $1.8 \mathrm{a}$ & 3.7 & $7.1 \mathrm{~b}$ \\
\hline & 10 & $3.0 \mathrm{a}$ & $1.1 \mathrm{a}$ & 3.6 & $7.7 \mathrm{ab}$ \\
\hline & 15 & $2.9 \mathrm{a}$ & $1.6 \mathrm{a}$ & 3.8 & $8.3 \mathrm{ab}$ \\
\hline & 20 & $3.1 \mathrm{a}$ & $1.6 \mathrm{a}$ & 4.1 & $8.8 \mathrm{a}$ \\
\hline \multirow{4}{*}{$\begin{array}{l}\text { チェリー } \\
\text { テッシノ }\end{array}$} & 5 & $2.6 \mathrm{~b}$ & $0.6 \mathrm{~b}$ & 4.0 & $7.2 \mathrm{~b}$ \\
\hline & 10 & $2.8 \mathrm{ab}$ & $1.1 \mathrm{~b}$ & 3.9 & $7.8 \mathrm{ab}$ \\
\hline & 15 & $2.9 \mathrm{ab}$ & $2.2 \mathrm{a}$ & 3.6 & $8.7 \mathrm{ab}$ \\
\hline & 20 & $3.1 \mathrm{a}$ & $2.3 \mathrm{a}$ & 3.9 & $9.3 \mathrm{a}$ \\
\hline \multirow{3}{*}{ 分散分析 ${ }^{\mathrm{y}}$} & 夜温 & $* *$ & $* *$ & ns & $*$ \\
\hline & 品種 & * & ns & ns & ns \\
\hline & 交互作用 & $*$ & $* *$ & ns & ns \\
\hline
\end{tabular}

z 同一品種間に执いて Tukey の多重検定により同符号間には $5 \%$ 水準で有意差のないことを示す

$\mathrm{y}$ 分散分析により**は $1 \%, *$ は $5 \%$ 水準で有意差あり, ns は 有意差なし

本試験の結果から夜温は側枝の伸長速度に関係し, 冬季に 採花する 2 次摘心側枝に及ぼす影響が大きいことが明らか となった．品種間でみると 'LPB' では夜温 $5^{\circ} \mathrm{C}$ と $10^{\circ} \mathrm{C}$, ‘CT’ では夜温 $10^{\circ} \mathrm{C}$ と $15^{\circ} \mathrm{C}$ で, 2 次摘心側枝の生育差が 認められ, 夜温の効果は品種間で異なることが示唆された.

到花日数は, 1 次側枝, 2 次摘心側枝拈よび 2 次側枝のい ずれに扣いても夜温が高いほど短くなることが認められ た. 到花日数は 'LPB' では(1)夜温 $5^{\circ} \mathrm{C}$, (2)夜温 $10^{\circ} \mathrm{C}$ と $15^{\circ} \mathrm{C}$, (3)夜温 $20^{\circ} \mathrm{C}$ の 3 段階, 'CT' では(1)夜温 $5^{\circ} \mathrm{C}$ と $10^{\circ} \mathrm{C}$, (2)夜温 $15^{\circ} \mathrm{C}$ と $20^{\circ} \mathrm{C}$ の 2 段階にお打む社区分された. スタ

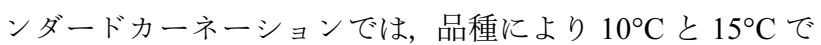

生育開花反応が異なることが報告されており（三浦ら, 1989), スプレーカーネーションの基本的な開花特性もこれ に類似していると考えられた.

同一夜温における到花日数は，2次摘心側枝で 'LPB’ が “CT’より短い場合もみられることから, 夜温の効果の違 いはそれぞれの品種の温度に対する反応性に起因している ものと考えられた。側枝別では 2 次摘心側枝が最も夜温の 違いによる到花日数の差が大きく, 1 次側枝と 2 次側枝の 到花日数で品種間に有意な差が認められたことから, ‘CT' の方が温度に対する反応性が高く，低温の時期ほど夜温の 影響が強く現れると考えられた。

いずれの品種でも，夜温が高くなるほど採花本数が増加 した. 時期別にみると 3 月末までの採花本数の増加量が総 採花本数に影響を及ぼしていることが示された. すなわち, スプレーカーネーションの生産性を高めるためには， 3 月 末までの採花本数を増加させることが重要と考えられた. 本試験では, 夜温設定を $5 \sim 20^{\circ} \mathrm{C}$ で $5^{\circ} \mathrm{C}$ 間隔としたが, 総採花本数の違いを処理ごとに品種間で比較すると, 夜温 が $5^{\circ} \mathrm{C}$ 上昇した場合, ‘LPB’では株当たり $0.5 \sim 0.6$ 本, “CT'では株当たり $0.5 \sim 0.9$ 本それぞれ増加した. 特に “CT' の採花本数は夜温 $15^{\circ} \mathrm{C}$ 以上で顕著に増加した. この ことから ‘CT'は 'LPB'より夜温に対する反応性が高い と考えられた. 時期別では年内の採花本数で品種間差が, 年内と $1 \sim 3$ 月の採花本数で交互作用が認められた. これ は, 夜温 $5^{\circ} \mathrm{C}$ に打ける, ‘LPB'の 1 次側枝の一部が 1 月以 降に採花されたことにより，1～ 3 月の採花本数が他の 3 区より増加したため，交互作用として検出されたものと考 えられた。

切り花品質では特に2次摘心側枝において夜温の影響が大 きく, 到花日数や採花本数と同じく, 冬季の低温期活ど夜温

第 3 表 冬季夜温がスプレーカーネーションの側枝別切り花特性に及ぼす影響

\begin{tabular}{|c|c|c|c|c|c|c|c|c|c|c|c|c|c|c|c|c|c|c|c|}
\hline \multirow[b]{2}{*}{$\begin{array}{l}\text { 供試 } \\
\text { 品種 }\end{array}$} & \multirow[b]{2}{*}{$\begin{array}{l}\text { 夜温 } \\
\left({ }^{\circ} \mathrm{C}\right)\end{array}$} & \multicolumn{6}{|c|}{1 次側枝 ${ }^{z}$} & \multicolumn{6}{|c|}{2 次摘心側枝 ${ }^{y}$} & \multicolumn{6}{|c|}{2 次側枝 $x$} \\
\hline & & $\begin{array}{l}\text { 切り } \\
\text { 花長 } \\
(\mathrm{cm})\end{array}$ & $\begin{array}{l}\text { 切り } \\
\text { 花重 } \\
(\mathrm{g})\end{array}$ & $\begin{array}{l}\text { 切り花 } \\
\text { 節数 } \\
\text { (節) }\end{array}$ & $\begin{array}{l}\text { 節間w } \\
\text { 長 } \\
(\mathrm{cm})\end{array}$ & $\begin{array}{l}1 \text { 次 }^{\mathrm{v}} \\
\text { 花らい } \\
\text { 数(花) }\end{array}$ & $\begin{array}{l}\text { 全u } \\
\text { 花らい } \\
\text { 数(花) }\end{array}$ & $\begin{array}{l}\text { 切り } \\
\text { 花長 } \\
(\mathrm{cm})\end{array}$ & $\begin{array}{l}\text { 切り } \\
\text { 花重 } \\
(\mathrm{g})\end{array}$ & $\begin{array}{l}\text { 切り花 } \\
\text { 節数 } \\
\text { (節) }\end{array}$ & $\begin{array}{l}\text { 節間 } \\
\text { 長 } \\
(\mathrm{cm})\end{array}$ & $\begin{array}{l}1 \text { 次 } \\
\text { 花らw } \\
\text { 数(花) }\end{array}$ & $\begin{array}{l}\text { 全花 } \\
\text { 5W } \\
\text { 数 (花) }\end{array}$ & $\begin{array}{l}\text { 切り } \\
\text { 花長 } \\
(\mathrm{cm})\end{array}$ & $\begin{array}{l}\text { 切り } \\
\text { 花重 } \\
(\mathrm{g})\end{array}$ & $\begin{array}{l}\text { 切り花 } \\
\text { 節数 } \\
\text { (節) }\end{array}$ & $\begin{array}{l}\text { 節間 } \\
\text { 長 } \\
(\mathrm{cm})\end{array}$ & $\begin{array}{l}\text { 1次 } \\
\text { 花らい } \\
\text { 数(花) }\end{array}$ & $\begin{array}{l}\text { 全花 } \\
\text { らい } \\
\text { 数(花) }\end{array}$ \\
\hline \multirow{4}{*}{$\begin{array}{l}\text { ライト } \\
\text { ピンク } \\
\text { バーバラ }\end{array}$} & 5 & 57.3 & $34.1 \mathrm{a}^{\mathrm{t}}$ & 7.6 & 7.5 & 5.7 & 6.7 & $81.5 \mathrm{a}$ & $76.1 \mathrm{a}$ & $14.0 \mathrm{~b}$ & $8.1 \mathrm{a}$ & $6.6 \mathrm{a}$ & $18.9 \mathrm{a}$ & $75.2 \mathrm{a}$ & 62.0 & $14.6 \mathrm{~b}$ & $8.3 \mathrm{a}$ & 6.9 & 13.3 \\
\hline & 10 & 57.0 & $30.6 \mathrm{ab}$ & 7.9 & 7.8 & 5.8 & 6.4 & $72.9 \mathrm{~b}$ & $65.5 \mathrm{ab}$ & $14.0 \mathrm{~b}$ & $7.2 \mathrm{ab}$ & $6.1 \mathrm{ab}$ & $15.4 \mathrm{ab}$ & $73.9 \mathrm{ab}$ & 64.6 & $15.7 \mathrm{~b}$ & $8.2 \mathrm{a}$ & 6.6 & 13.3 \\
\hline & 15 & 59.3 & $33.4 \mathrm{ab}$ & 7.9 & 7.7 & 5.7 & 6.6 & $68.7 \mathrm{bc}$ & c $60.8 \mathrm{bc}$ & $=14.7 \mathrm{~b}$ & $6.9 \mathrm{~b}$ & $6.2 \mathrm{ab}$ & $12.3 \mathrm{bc}$ & $66.8 \mathrm{c}$ & 73.3 & $17.0 \mathrm{ab}$ & $7.1 \mathrm{~b}$ & 6.6 & 14.4 \\
\hline & 20 & 58.5 & $29.5 \mathrm{~b}$ & 8.0 & 7.9 & 5.6 & 6.3 & $67.1 \mathrm{c}$ & $47.3 \mathrm{c}$ & $15.9 \mathrm{a}$ & $5.9 \mathrm{c}$ & $5.9 \mathrm{~b}$ & $9.9 \mathrm{c}$ & $67.9 \mathrm{bc}$ & 66.5 & $18.7 \mathrm{a}$ & $6.0 \mathrm{c}$ & 6.3 & 11.8 \\
\hline \multirow[t]{2}{*}{ 有意性 ${ }^{s}$} & & ns & * & ns & ns & ns & ns & $*$ & $* *$ & $*$ & $*$ & $*$ & $* *$ & $* *$ & ns & $*$ & * & ns & $\mathrm{ns}$ \\
\hline & 5 & 60.2 & $25.1 \mathrm{a}$ & 8.8 & 6.5 & 4.9 & 5.2 & $88.3 \mathrm{a}$ & $65.2 \mathrm{a}$ & $15.4 \mathrm{~b}$ & $7.6 \mathrm{a}$ & $6.6 \mathrm{a}$ & $12.5 \mathrm{a}$ & $79.8 \mathrm{a}$ & $45.8 \mathrm{a}$ & $14.7 \mathrm{~b}$ & $7.7 \mathrm{a}$ & $7.4 \mathrm{a}$ & $8.7 \mathrm{a}$ \\
\hline \multirow{3}{*}{$\begin{array}{l}\text { チェリー } \\
\text { テッシノ }\end{array}$} & 10 & 59.5 & $24.4 \mathrm{ab}$ & 8.6 & 6.7 & 4.9 & 5.1 & $74.6 \mathrm{~b}$ & $53.6 \mathrm{~b}$ & $15.8 \mathrm{~b}$ & $6.1 \mathrm{~b}$ & $6.5 \mathrm{a}$ & $7.7 \mathrm{~b}$ & $70.1 \mathrm{bc}$ & $44.8 \mathrm{ab}$ & b $16.3 \mathrm{~b}$ & $6.8 \mathrm{a}$ & $6.3 \mathrm{~b}$ & $7.3 \mathrm{ab}$ \\
\hline & 15 & 60.6 & $23.4 \mathrm{ab}$ & 8.8 & 6.4 & 4.8 & 5.1 & $75.2 \mathrm{~b}$ & $44.6 \mathrm{c}$ & $15.8 \mathrm{~b}$ & $5.6 \mathrm{bc}$ & $6.2 \mathrm{a}$ & $6.2 \mathrm{c}$ & $65.7 \mathrm{c}$ & $43.2 \mathrm{ab}$ & b $15.1 \mathrm{~b}$ & $5.4 \mathrm{~b}$ & $6.1 \mathrm{~b}$ & $6.4 \mathrm{bc}$ \\
\hline & 20 & 58.4 & $22.0 \mathrm{~b}$ & 8.4 & 6.8 & 4.9 & 5.0 & $77.7 \mathrm{~b}$ & $31.6 \mathrm{~d}$ & $18.4 \mathrm{a}$ & $4.9 \mathrm{c}$ & $4.6 \mathrm{~b}$ & $4.6 \mathrm{~d}$ & $73.7 \mathrm{~b}$ & $37.2 \mathrm{~b}$ & $20.3 \mathrm{a}$ & $3.9 \mathrm{c}$ & $4.8 \mathrm{c}$ & $4.9 \mathrm{c}$ \\
\hline 有意性 & & ns & $*$ & ns & ns & ns & ns & $* *$ & $*$ & $* *$ & $*$ & $* *$ & $*$ & $*$ & $*$ & $* *$ & $* *$ & $*$ & $* *$ \\
\hline
\end{tabular}

\footnotetext{
$\mathrm{z}$ 第 1 図参照, 1 次側枝 3 本の平均

$\mathrm{y}$ 第 1 図参照, 2 次摘心側枝 2 本の平均

$\mathrm{x}$ 第 1 図参照, 調査株の最も早い 2 次側枝の切り花特性

w第 $4 \sim 5$ 節の長さ

$\mathrm{v}$ 頂花を除いた側花の花らい数

u頂花を除いた 1 次花らい数と 2 次花らい数の合計

${ }^{\mathrm{t}}$ Tukey の多重検定により同符号間には 5\%水準で有意差のないことを示す

$\mathrm{s}$ 分散分析により**は $1 \%$ * * $5 \%$ 水準で有意差あり, ns は有意差なし
} 
第 4 表 冬季夜温がカーネーションの時期別花弁色差に及ぼす影響

\begin{tabular}{|c|c|c|c|c|c|c|c|c|c|c|c|c|c|c|c|c|c|c|c|c|}
\hline \multirow{3}{*}{$\begin{array}{l}\text { 供試 } \\
\text { 品種 }\end{array}$} & \multirow{3}{*}{$\begin{array}{l}\text { 夜温 } \\
\left({ }^{\circ} \mathrm{C}\right)\end{array}$} & \multirow{3}{*}{$\begin{array}{l}\text { 調査 } \\
\text { 花数 } \\
\text { (花) }\end{array}$} & \multicolumn{6}{|c|}{2007 年 11 月 29 日 } & \multicolumn{6}{|c|}{2008 年 3 月 3 日 } & \multicolumn{6}{|c|}{2008 年 5 月 8 日 } \\
\hline & & & \multicolumn{3}{|c|}{ 中央部 z } & \multicolumn{3}{|c|}{ 外縁部 y } & \multicolumn{3}{|c|}{ 中央部 } & \multicolumn{3}{|c|}{ 外縁部 } & \multicolumn{3}{|c|}{ 中央部 } & \multicolumn{3}{|c|}{ 外縁部 } \\
\hline & & & $\mathrm{L}^{*}$ & $a^{*}$ & $\mathrm{~b}^{*}$ & $\mathrm{~L}^{*}$ & $a^{*}$ & $b^{*}$ & $\mathrm{~L}^{*}$ & $a^{*}$ & $b^{*}$ & $\mathrm{~L}^{*}$ & $a^{*}$ & $b^{*}$ & $\mathrm{~L}^{*}$ & $a^{*}$ & $b^{*}$ & $\mathrm{~L}^{*}$ & $a^{*}$ & $b^{*}$ \\
\hline \multirow{4}{*}{$\begin{array}{l}\text { ライト } \\
\text { ピンク } \\
\text { バーバラ }\end{array}$} & 5 & 10 & 78.7 & 25.2 & 1.5 & 78.1 & 27.3 & 1.2 & $81.4 \mathrm{a}^{\mathrm{x}}$ & 20.4 & $0.9 \mathrm{a}$ & $81.4 \mathrm{ab}$ & 18.7 & $0.4 \mathrm{ab}$ & 82.8 & 18.4 & $1.9 \mathrm{a}$ & 83.4 & 15.8 & 1.7 \\
\hline & 10 & 10 & 78.5 & 25.9 & 1.1 & 77.9 & 25.9 & 1.0 & $80.1 \mathrm{~b}$ & 22.7 & $0.4 \mathrm{~b}$ & $80.9 \mathrm{~b}$ & 19.4 & $0.1 \mathrm{~b}$ & 82.8 & 17.8 & $1.3 \mathrm{~b}$ & 83.5 & 15.2 & 1.2 \\
\hline & 15 & 10 & 78.4 & 25.9 & 1.1 & 78.1 & 25.3 & 1.9 & $81.0 \mathrm{ab}$ & 21.0 & $0.1 \mathrm{~b}$ & $81.6 \mathrm{ab}$ & 17.8 & $0.0 \mathrm{~b}$ & 83.3 & 17.0 & $1.9 \mathrm{a}$ & 83.9 & 14.8 & 1.8 \\
\hline & 20 & 10 & 79.5 & 23.8 & 1.3 & 79.6 & 23.8 & 1.7 & $81.5 \mathrm{a}$ & 19.6 & $1.1 \mathrm{a}$ & $82.3 \mathrm{a}$ & 17.4 & $1.0 \mathrm{a}$ & 83.9 & 16.0 & $1.8 \mathrm{ab}$ & 84.3 & 14.2 & 1.8 \\
\hline \multirow[t]{2}{*}{ 有意性 w } & & & ns & ns & ns & ns & ns & $\mathrm{ns}$ & * & ns & * & $*$ & ns & $* *$ & ns & ns & * & ns & ns & ns \\
\hline & 5 & 10 & $58.8 \mathrm{a}$ & $53.2 \mathrm{c}$ & $5.9 \mathrm{ab}$ & $80.6 \mathrm{a}$ & $17.5 \mathrm{~b}$ & 1.6 & $66.5 \mathrm{a}$ & $46.2 \mathrm{c}$ & $-0.5 \mathrm{c}$ & $82.8 \mathrm{a}$ & $15.4 \mathrm{c}$ & $0.7 \mathrm{~b}$ & $62.3 \mathrm{a}$ & 52.0 & 5.0 & $83.9 \mathrm{a}$ & $12.9 \mathrm{~b}$ & $1.6 \mathrm{a}$ \\
\hline \multirow{3}{*}{$\begin{array}{l}\text { チェリー } \\
\text { テッシノ }\end{array}$} & 10 & 10 & $60.3 \mathrm{a}$ & $55.3 \mathrm{bc}$ & $8.0 \mathrm{a}$ & $74.6 \mathrm{~b}$ & $22.7 \mathrm{~b}$ & 2.0 & $60.8 \mathrm{~b}$ & $55.3 \mathrm{~b}$ & $7.4 \mathrm{~b}$ & $83.1 \mathrm{a}$ & $15.0 \mathrm{c}$ & $1.8 \mathrm{ab}$ & $59.9 \mathrm{ab}$ & 53.7 & 6.4 & $82.0 \mathrm{a}$ & $15.6 \mathrm{~b}$ & $1.0 \mathrm{a}$ \\
\hline & 15 & 10 & $53.4 \mathrm{~b}$ & $60.6 \mathrm{a}$ & $1.0 \mathrm{c}$ & $57.0 \mathrm{c}$ & $59.0 \mathrm{a}$ & 2.7 & $54.5 \mathrm{c}$ & $60.1 \mathrm{a}$ & $11.2 \mathrm{a}$ & $71.7 \mathrm{~b}$ & $31.9 \mathrm{~b}$ & $2.2 \mathrm{a}$ & $58.8 \mathrm{~b}$ & 54.4 & 5.1 & $80.2 \mathrm{a}$ & $18.0 \mathrm{~b}$ & $-0.1 \mathrm{~b}$ \\
\hline & 20 & 10 & $56.4 \mathrm{ab}$ & $58.0 \mathrm{ab}$ & $3.3 \mathrm{bc}$ & $57.4 \mathrm{c}$ & $58.6 \mathrm{a}$ & 2.5 & $53.3 \mathrm{c}$ & $59.7 \mathrm{a}$ & $-1.4 \mathrm{c}$ & $58.9 \mathrm{c}$ & $49.0 \mathrm{a}$ & $-3.1 \mathrm{c}$ & $59.2 \mathrm{~b}$ & 54.3 & 4.7 & $72.1 \mathrm{~b}$ & $31.4 \mathrm{a}$ & $-0.6 b$ \\
\hline 有意 & & & $*$ & $*$ & $* *$ & $* *$ & $* *$ & ns & $* *$ & $* *$ & $* *$ & $* *$ & $* *$ & * & $*$ & ns & $\mathrm{ns}$ & $* *$ & $* *$ & $* *$ \\
\hline
\end{tabular}

$\mathrm{z}$ 花弁中央部の色差, 側花の最外縁花弁を調査

$\mathrm{y}$ 花弁の外縁部の色差, 側花の最外縁花弁を調査

${ }^{\mathrm{x}}$ Tukey の多重検定により同符号間には 5\%水準で有意差のないことを示す

w 分散分析により**は 1\%,*は5\%水準で有意差あり, ns は有意差なし

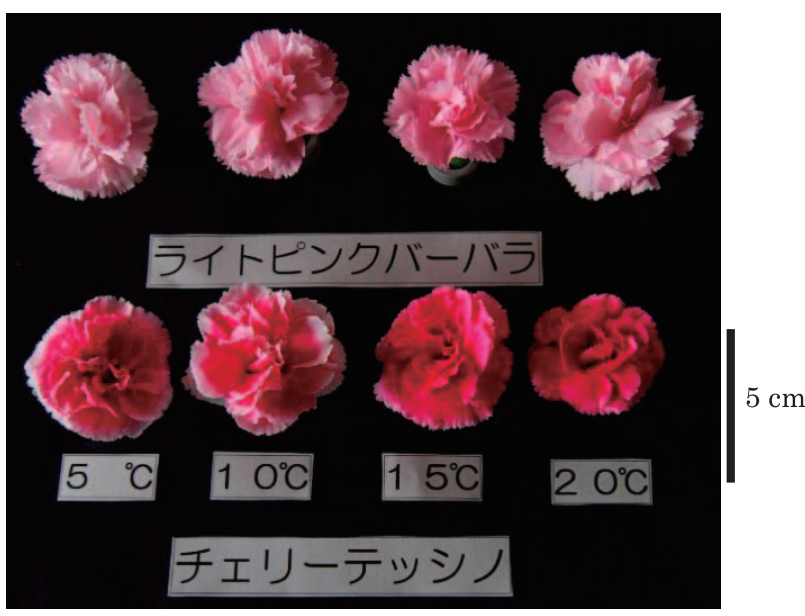

第 4 図 冬季夜温がスプレーカーネーションの花色に及ぼす 影響

z 2007 年 11 月 23 日撮影, 上段 ‘ライトピンクバーバラ’, 下段 ‘チェリーテッシノ’

の影響が顕著に現れることから, スタンダードカーネーショ ンと同様（國本ら，1989）, 品質面においても冬季の夜温管 理が重要であることが示された. 調査項目のらちスプレー カーネーションの切り花品質として重要な花らい数に注目 すると, 藤野ら（1982）の報告にあるように, 夜温が低いほ ど全花らい数が増加し, 特に冬季に開花する 2 次摘心側枝に おいて顕著な差が認められた. スプレーカーネーションでは 2 次花らいが多くなり，1 次花らいよりも高い位置に着生す ると草姿に悪影響を与える（細谷，1999）。また，1 次花ら い数が 3 輪以下では切り花の評価が低くなる. 本試験に打け る全花らい数は, 1 次花らいと 2 次花らいの合計数を示して 扣り，花らい数からみた場合，“LPB’，“CT’ともに10〜 $15^{\circ} \mathrm{C}$ が好適な冬季夜温の範囲と推察された。

また, 夜温 $20^{\circ} \mathrm{C}$ では 2 次摘心側枝拉よび 2 次側枝で節 間長が短くなり，切り花節数が増加した. カーネーション
は 12 時間以上の日長で長日ほど花芽分化が促進され, 低照 度で短日の場合は開花が著しく遅くなる（小西，1980）。本 試験に拈いて両品種とも夜温 5,10 および $15^{\circ} \mathrm{C}$ に比べ夜 温 $20^{\circ} \mathrm{C}$ の 2 次摘心側枝および 2 次側枝の切り花節数が増 加していた．本試験では日長操作をしていないため厳密な 比較はできないが，夜温の違いにより側枝の生育時期が異 なった結果，自然日長の違いが 2 次摘心側枝扔よび 2 次側 枝の切り花節数に影響したと考えられた.

夜温の違いが花弁の花色に及ぼす影響は，品種間で異 なった。すなわち ‘LPB’では 3 月 3 日調査での久花弁中 央部拈よび外縁部の明度 $\mathrm{L}^{*}$ と $\mathrm{b}^{*}$ に夜温の違いによる差が 検出されたものの, 夜温との間に一定の傾向は認められず, 観察による視覚的な差は小さかった. これに対し，“CT’ では夜温が高くなるほど明度 $\mathrm{L}^{*}$ が低下寸るとともに， $\mathrm{a}^{*}$

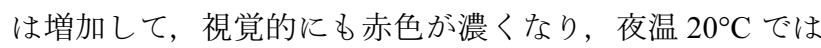
覆輪の白色部分が発現しないものがあった。 ‘CT’におけ るこの現象は， $4 \sim 5$ 月の外気温が上昇する時期には目立 たなくなった。 スタンダードカーネーションにおいては花 色発現に及ぼす温度の影響が報告されており，夜温が高す ぎると花色が濃くなり，低すぎると花色が薄くなる (Holley・Baker, 1963). スプレーカーネーションの花弁に 打いてもこれと注同様の傾向が認められるとともに，花 色の発現に品種間差がみられた.

次に調査時期別の花色についてみると, 'LPB' では 3 月 以降の調査において明度 $\mathrm{L} *$ が増加してa*が低下した。 ‘CT’ では 5 月の調査で明度 L*が増加する傾向を示したが，調 査時期よりも夜温が花色発現に与える影響が大きかった. スタンダードカーネーションでは, $12 \sim 1$ 月に花弁のアン トシアニン含量が増加する（Maekawa・Nakamura, 1976）と の報告もある. 今後, スプレーカーネーションに拈いても, 花弁のアントシアニン含量に及ぼす時期別执よび夜温の影 響について調査する必要があると考えられた.

カーネーション以外の花き類でも, 温度が花色の発現に 
影響を及ぼすことが知られており，バラでの低夜温での白 花化（水戸・万豆, 1973）や，ペチュニアに打怕地に 紫の覆輪品種が, $30 \sim 35^{\circ} \mathrm{C}$ の高温で全体が紫に, $15^{\circ} \mathrm{C} て ゙$ 花弁全体が白くなる現象（リュンガー，1978）が知られて いる. トルコギキョウの花弁に打いては, 白地に紫覆輪花 弁で，覆輪着色面積率が季節変動し，採花前の高温で花弁 の着色面積率が小さくなり, 昼温が低い状態が継続すると 着色面積率が高くなるとの報告がある（渡辺，2006）。福 田・中山（2008）は，トルコギキョウの $20^{\circ} \mathrm{C}$ 一定条件で 着色面積率が増し, 昼温よりも夜温が高い条件で着色面積 率が減少したと報告している. 品目が異なるため直接の比 較はできないものの, 供試品種の‘CT’の開花過程におい てもペチュニアの発現のように, 高夜温が白色覆輪の減少 や赤色発現の増加に影響を与兄ていると考兄られた。

本試験では, 夜温の上昇により到花日数が減少し, 採花 本数が増加するなどの効果が認められた．この一方で夜温 $20^{\circ} \mathrm{C}$ では軟弱花が発生するとともに, 1 次花らい数が顕著 に減少したり, 花色発現への悪影響もみられた。 これに対 し, 夜温 $5^{\circ} \mathrm{C}$ では 2 次花らい数の増加や花色の発現不良な ぞの悪影響がみられた。本試験の結果からみて, スプレー カーネーション 'LPB' と'CT' においては夜温 $10 \sim 15^{\circ} \mathrm{C}$ の範囲で切り花品質に悪影響の少ない切り花が得られるこ とが明らかとなった，暖房コストを抑㒸るためには低い冬 季夜温管理が求めら机るが, 切り花品質からみた場合, $10^{\circ} \mathrm{C}$ 未満の夜温管理では 2 次花らい数の増加など切り花品 質に悪影響が生じる可能性があると考えられた。

本試験では日中の換気設定温度を $20^{\circ} \mathrm{C}$ 区のみ $25^{\circ} \mathrm{C}$ 設定 としたが, $20^{\circ} \mathrm{C}$ 区の気温は夜間, 日中も含めほぼ $19^{\circ} \mathrm{C} \sim$ $23^{\circ} \mathrm{C}$ で推移し, 日中の最高気温が他の試験区よりも低い場 合もあったため, 日中の試験区内の温度差よりも夜温の違 いが生育に与える影響が大きいと考兄られた。

また，栽培床にスーパードレンベッドを使用し，地温が 気温の影響を受けやすい条件下での試験であったが，夜温 $5^{\circ} \mathrm{C}$ でも地温が $9^{\circ} \mathrm{C}$ 以上に保たれており, 通常の温度管理 では地温は問題にならない（小西，1980）ことから, 地温 よりも気温が切り花品質に与える影響が大きいと推察され た. 生産現場ではカーネーションは地床と隔離床の双方で 栽培されて和り（田中，1996）, 本試験で使用したポリプロ ピレン製隔離床の使用事例もある. 静岡県内の産地でも地

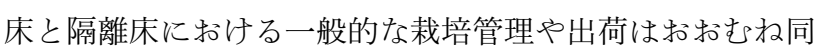
一飞行わ机ている. このことから, 本試験の結果は, 現地 に抢けるスプレーカーネーションの夜温管理についての基 礎的データになると考兄られた。

なお, カーネーションでは, これまでにスタンダードカー ネーションを供試して変温管理が生育に及ぼす影響（藤野 ら，1977a; 佐本ら，1977; 武田ら，1975）が報告されている ほか，キクなどでは燃料使用量を軽減させるための EOD (End of Day)-heating なども試みられている（道園ら，2008）. 今後は, スプレーカーネーションに扮いても, 暖房コスト
を抑えながら切り花品質や収量を維持するためにも，夜温 $10 \sim 15^{\circ} \mathrm{C}$ を基本とした変温管理を含む効率的な暖房方法 について検討していく必要があると考えられた.

\section{摘 要}

スプレーカーネーション (Dianthus Caryophyllus L.) 'ラ イトピンクバーバラ (LPB)'と ‘チェーテッシノ $(\mathrm{CT})$ ' を冬季夜温 $5,10,15$ および $20^{\circ} \mathrm{C}$ で栽培し, 生育, 収量 および切り花品質を調査した。両品種とも夜温が高いほど 2 次摘心側枝の伸長速度が早いが，切り花長は夜温 $5^{\circ} \mathrm{C}$ が 最も長くなった．両品種とも夜温が高くなるほど到花日数 が短縮し, 採花本数が増加した. 切り花品質については, 夜温 $5^{\circ} \mathrm{C} て ゙ 2$ 次花らい数の増加などの悪影響が認められた. また ‘LPB’の花色は夜温の影響が少なく安定していたが， 'CT' は花色, 花弁外縁部の白色覆輪面積ともに夜温の影

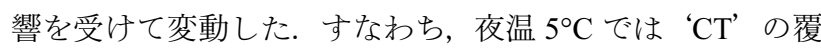
輪面積が広く明膫であったが, 夜温が高い注ど赤色が濃く なり白色覆輪が不鮮明となった。 これらのことから, 生産 性と切り花品質の両立の観点から, 'LPB', 'CT' と妇に $10 \sim 15^{\circ} \mathrm{C}$ が好適な冬季夜温の範囲と推察された。

\section{引用文献}

Abou Dahab, A. M. 1967. Effects of light and temperature on growth and flowering of carnation (Dianthus caryophyllus L.). Mededelingen Landbouwhogeschool Wageningen 6713: $1-68$.

道園美弦・久松 完・川西孝秀・島 浩二・柴田道夫. 2008 . 異なる生育温度環境下でのキクの開花に及ぼす EODheating の効果. 園学研. 7 (別2): 316 .

藤野守弘・藤原辰行・藤本治夫. 1982. 環境制御による温 室カーネーション花茎品質の改善 (第2 報)。生長と開 花に打よぼす低夜温と日長の影響. 兵庫農総七研報. 30: 49-55.

藤野守弘・柴田 進・藤本治夫. 1977a. カーネーションの 生長と開花に括よぼす夜温の影響. 兵庫農総七研報. 26: 29-33.

藤野守弘・柴田 進・藤本治夫. 1977b. カーネーションの 生長と開花に打よぼす夜温, 施肥濃度掞よび潅水回数 の影響. 兵庫農総七研報. 26: 34-39.

福田直子・中山真義. 2008. 温度条件がトルコギキョウ覆 輪花弁の着色面積率に及ぼす影響. 園学研. 7: 531-536.

肥田和夫. 1973. カーネーションの営利栽培. p. 44-52. 農 業図書. 東京.

Holley, W. D. and R. Baker. 1963. Carnation production. p. 3872. WM. C. Brown Co. Inc., Iowa.

堀川法隆. 1979. スプレー咲きカーネーションの頂芽の摘 除時期が切花草姿に拉よぼす影響. 園学要旨. 昭 54 秋 : 524 .

細谷宗令. 1999. 生育過程と技術. p. 123-130. 農業技術体 
系花卉編. 7. カーネーション（ダイアンサス）/バ ラ. 農文協. 東京.

鍵野優子. 2009. カーネーション. p. 246 の 2-7. 農業技術

体系花卉編. 7. カーネーション（ダイアンサス）/バ

ラ. 農文協. 東京.

加藤俊博. 1997. 養液管理. p. 481-512. 農業技術体系花卉

編. 7. カーネーション (ダイアンサス) /バラ. 農文

協. 東京.

小西国義. 1980. カーネーションの生産技術. p. 148-178. 養賢堂. 東京.

國本忠正. 1993. スプレイカーネーションの生育, 開花に

関する研究（第 2 報）摘蕾時期が開花に及ぼす影響と

開花特性の品種間差. 大分熱花試研報. 3:13-23.

國本忠正・東禮一郎・後藤俊之. 1989. 施設花きの発育段

階別温度の設定に関寸る研究 II 温室カーネーション

の冬季夜温管理. 大分熱花試研報. 2: 12-26.

Maekawa, S. and N. Nakamura. 1976. Studies on the coloration of carnation flowers VI. Seasonal change of antocyanin content in intact petals. Sci. Rept. Fac. Agr. Kobe. Univ. 12: 35-39.

水戸喜平・万豆剛一. 1973. バラの切り花生産に及ぼす夜 温の影響. 静岡農試研報. 18: 82-93.

三浦泰昌・村上 高・小林宏信. 1989. 夜温がカーネーショ ンの生育ならびに ${ }^{14} \mathrm{C}$ - 同化産物の転流におよぼす影響 の品種間差異. 園学雑. 58: 421-427.

リュンガー, ワルター. 1978. 園芸植物の開花生理と栽培 (浅平 端・中村英司訳). p. 136-145. 誠文堂新光社. 東京.
佐本啓智・中川 脩・大西謙二. 1977. カーネーション温 室の温度制御について. 園学要旨. 昭 52 春: 324-325. 武田恭明・竹島疆二・中村英司. 1975. 温室カーネーショ ンに拈ける冬期夜温のプログラム調節. 園学要旨. 昭 50秋: 300-301.

田中俊光. 1996. カーネーション. p. 227-234. 農業技術体 系花卉編. 7. カーネーション（ダイアンサス）／バ ラ. 農文協. 東京.

宇田 明. 2004. 品種・系統と栽培特性. p. 47-56. 農業技 術体系花卉編. 7. カーネーション（ダイアンサス） バラ. 農文協. 東京.

宇田 明. 2009. 主要品種の特性と選択のポイント. p. 149156. 最新農業技術. 花卉 Vol. 1. 農文協. 東京.

臼井冨太. 1999. カーネーション国内産地の現状と課題 [1]. 農及園. 74: 845-850.

米村浩次. 1990a. 温度管理. p. 88-98. 米村浩次編著. 切 り花栽培の新技術「カーネーション」上巻. 誠文堂新 光社. 東京.

米村浩次. 1990b. 摘心と仕立て法. p. 103-118. 米村浩次 編著. 切り花栽培の新技術「カーネーション」下巻. 誠文堂新光社. 東京.

吉田 茂. 1984. スプレーカーネーションの切り花形態と 将来性. 農及園. 59: 456-460.

渡辺 功. 2006. トルコギキョウ覆輪花弁に打ける着色割 合の季節変動. 園学研. 5: 409-413.

（財）花普及センタ一。2008. 2007 年に拈ける花きの品種 別流通動向分析調査. 〈www.jfpc.or.jp/〉. 